\title{
Pityriasis lichenoides et varioliformis acuta as presenting feature of acute human immunodeficiency virus infection
}

\author{
Maria Relvas, Luís Santiago, José Carlos Cardoso, Hugo Oliveira
}

Department of Dermatology, Hospitals of Coimbra University, Coimbra, Portugal

\section{Correspondence to Dr Maria Relvas, mariavrelvas@gmail.com}

Accepted 7 August 2019

\section{DESCRIPTION}

We describe a case of a 38-year-old woman who presented to the emergency department with a 2-day history of generalised cutaneous rash associated with fever, chills and odynophagia. The skin examination revealed an eruption of erythematous papules of various sizes and different stages of evolution distributed over the trunk, extremities, including palms and plants, and, less prominently, the face (figure 1A). Some of the lesions showed a vesicular centre, whereas others had a peripheral fine scale and tendency to healing (figure 1B). Erosions were also evident. At the buccal mucosa and tongue, multiple erythematous red patches consistent with oropharyngeal candidiasis were noticed.

Laboratory findings revealed a normal complete blood count, renal and liver function; $\mathrm{C}$ reactive protein was elevated. Syphilis screening was negative. HIV testing was performed, demonstrating a positive fourth generation antigen/antibody test, a negative ELISA and a viral load over 1.000.000 copies per millilitre. The patient was diagnosed with acute HIV infection.

Since the diagnosis of exanthema of primary HIV infection was unlikely, the patient underwent a skin biopsy. The histopathological examination exhibited multifocal parakeratosis (figure 2A), with sparse vacuoles in the basal layer and scattered apoptotic keratinocytes mainly in the lowest half of the Malpighian layer (figure 2B). The upper dermis showed perivascular lymphomononuclear infiltrate (figure 2C).

The correlation between clinical and histological findings was consistent with the diagnosis of pityriasis lichenoides et varioliformis acuta (PLEVA).

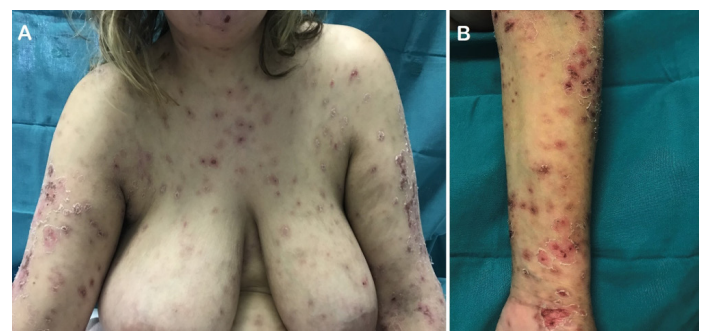

Figure 1 Erythematous papules of various sizes and different stages of evolution distributed over the trunk and extremities (A). Some showed a vesicular centre, whereas others had a peripheral fine scale and tendency to healing (B).

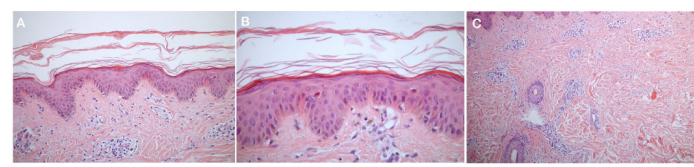

Figure 2 Histopathology of the lesions: multifocal parakeratosis $(A)$; sparse vacuoles in the basal layer and scattered apoptotic keratinocytes (B); perivascular lymphomononuclear infiltrate in the dermis (C).

The patient started topical corticosteroid and antiretroviral therapy 1 week later and the lesions improved.

PLEVA is a rare disease manifested by crops of erythematous papules, mostly affecting the trunk and extremities. Vesicles, crusts or ulcers, which can coexist in different lesions, commonly develop and heal in a period of weeks. ${ }^{12}$

The exact aetiology of PLEVA is still unknown. Some theories have been proposed to explain its pathogenesis: a lymphoproliferative origin, an immunocomplex-mediated response or an inflammatory reaction to infection. ${ }^{3} 4$ Multiple agents have been described, including $\beta$-hemolytic streptococci, Staphylococcus aureus, Toxoplasma gondii, parvovirus B19, Epstein-Barr virus, cytomegalovirus, varicella zoster virus, human herpesvirus 7 and HIV. ${ }^{5-7}$

Only a few cases of association between PLEVA and HIV have been reported. ${ }^{78}$ This situation could lead to a diagnostic challenge, with this dermatitis being mistaken for more common ones usually associated with HIV, such as primary exanthem of acute retroviral syndrome, herpes zoster or secondary syphilis.

The majority of cases regarding PLEVA in the setting of HIV occurred in the acute stages of the infection. Considering this, some authors postulate that dermatitis may be a marker of early to mid-stages of HIV disease. ${ }^{8}$

The described case corroborates this theory and its relevance is relying on two main aspects. The first encompasses the atypical cutaneous features, which unveiled to be PLEVA. The second refers to its association with HIV, that might help understand the pathogenesis of the disease and must be considered in the daily practice. Regarding this, the authors believe that HIV testing should be performed in the setting of PLEVA, especially if the patient exhibits other findings associated with impaired immunity. 


\section{Learning points}

- Pityriasis lichenoides et varioliformis acuta (PLEVA) is rare dermatitis which can be mistaken for more common ones usually associated with HIV, such as primary exanthem of acute retroviral syndrome, herpes zoster or secondary syphilis.

- PLEVA may be triggered by HIV and represent a marker of early to mid-stages of the infection.

- HIV testing should be performed in the setting of PLEVA, especially if the patient exhibits other findings associated with impaired immunity.

Contributors MR: corresponding author and responsible for the writing of the manuscript. LS and HO: made substantial contributions on the writing and review of the manuscript. JCC: contributed by performing histopathological examination.

Funding The authors have not declared a specific grant for this research from any funding agency in the public, commercial or not-for-profit sectors.

Competing interests None declared.
Patient consent for publication Obtained.

Provenance and peer review Not commissioned; externally peer reviewed.

\section{REFERENCES}

1 Bolognia JL, Schaffer JV, Cerroni L. Other Papulosquamous Disorders. Dermatology. 4 ed. Philadelphia: Elsevier Saunders, 2018.

2 Hood AF, Mark EJ. Histopathologic diagnosis of pityriasis lichenoides et varioliformis acuta and its clinical correlation. Arch Dermatol 1982:118:478-82.

3 Bowers S, Warshaw EM. Pityriasis lichenoides and its subtypes. J Am Acad Dermatol 2006:55-557-72.

4 Fernandes NF, Rozdeba PJ, Schwartz RA, et al. Pityriasis lichenoides et varioliformis acuta: a disease spectrum. Int I Dermatol 2010:49:257-61.

5 Fölster-Holst R, Zawar VP, Chuh A. Paraviral exanthems. Expert Rev Anti Infect Ther 2016;14:601-11.

6 Costa-Silva M, Calistru A, Sobrinho-Simões J, et al. Pitiriasis liquenoide y varioliforme aguda asociada al virus herpes humano tipo 7. Actas Dermo-Sifiliográficas 2018:109:e6-e10.

7 Ostlere LS, Langtry JA, Branfoot AC, et al. HIV seropositivity in association with pityriasis lichenoides et varioliformis acuta. Clin Exp Dermatol 1992;17:36-7.

8 Smith KJ, Nelson A, Skelton H, et al. Pityriasis lichenoides et varioliformis acuta in HIV$1+$ patients: a marker of early stage disease. The Military Medical Consortium for the Advancement of Retroviral Research (MMCARR). Int I Dermatol 1997;36:104-9.

Copyright 2019 BMJ Publishing Group. All rights reserved. For permission to reuse any of this content visit

https://www.bmj.com/company/products-services/rights-and-licensing/permissions/

BMJ Case Report Fellows may re-use this article for personal use and teaching without any further permission.

Become a Fellow of BMJ Case Reports today and you can:

- Submit as many cases as you like

- Enjoy fast sympathetic peer review and rapid publication of accepted articles

- Access all the published articles

Re-use any of the published material for personal use and teaching without further permission

\section{Customer Service}

If you have any further queries about your subscription, please contact our customer services team on +44 (0) 2071111105 or via email at support@bmj.com.

Visit casereports.bmj.com for more articles like this and to become a Fellow 